\title{
Pengaruh Serbuk Kaca dan Variasi Suhu Pembakaran pada Pembuatan Genteng Lempung Sedimentasi Banjir Kanal Timur Kota Semarang terhadap Kuat Tekan serta Daya Serapnya terhadap Air
}

\author{
Amaryllis Kartika Ratri ${ }^{\mathrm{a}}$, Sriatun ${ }^{\mathrm{a}}$, Adi Darmawan ${ }^{\mathrm{a}}$ \\ a Inorganic Laboratory, Chemistry Department, Faculty of Sciences and Matematics, Diponegoro University, Jalan Prof. Soedarto, \\ Tembalang, Semarang 50275, Telepon (024) 7474754 \\ * Corresponding author: adidarmawan@live.undip.ac.id
}

Abstract

The manufacture of tile originating clay sedimentation of Semarang East Flood Canal and the study of the effect of the addition of glass powder and variation of combustion temperature against the compressive strength and water absorption of the tile has been conducted. The glass powder used comes from used glass bottles. This study was conducted by (1) varying the amount of glass powder mixed in clays by $0 \%, 2 \%, 4 \%$, $6 \%, 8 \%, 10 \%, 12 \%, 14 \%, 16 \%, 18 \%$, and $20 \%$ And (2) varying the combustion temperature of $600^{\circ} \mathrm{C}, 700^{\circ} \mathrm{C}, 800^{\circ} \mathrm{C}$ and $900^{\circ} \mathrm{C}$. The resulting product was tested using FT-IR and then measured the compressive strength and water absorption. Measurement of compressive strength of tile is done by putting pressure on tile using compression test tool. While the measurement of water absorption is done by measuring the percentage of tile weight before and after being soaked into water for one night. The results showed that by increasing the combustion temperature will increase the value of compressive strength and decrease the absorption value of tile to water. The addition of a glass powder that provides the highest compressive strength value and the lowest water absorption is in the addition of $12 \%$ glass powder.

\section{Abstrak}

Telah dilakukan pembuatan genteng yang berasal lempung sedimentasi Banjir Kanal Timur Semarang dan dilakukan pula kajian pengaruh penambahan serbuk kaca dan variasi suhu pembakaran terhadap kuat tekan dan daya serap air genteng tersebut. Serbuk kaca yang digunakan berasal dari kaca botol bekas. Kajian ini dilakukan dengan (1) melakukan variasi penambahan jumlah serbuk kaca yang dicampurkan pada lempung sebanyak $0 \%, 2 \%, 4 \%, 6 \%, 8 \%, 10 \%, 12 \%, 14 \%, 16 \%, 18 \%$, dan $20 \%$ dan (2) melakukan variasi suhu pembakaran $600^{\circ} \mathrm{C}, 700^{\circ} \mathrm{C}, 800^{\circ} \mathrm{C}$ dan $900^{\circ} \mathrm{C}$. Produk yang dihasilkan diuji dengan menggunakan FT-IR kemudian diukur kuat tekan dan daya serap airnya. Pengukuran kuat tekan genteng dilakukan dengan memberikan tekanan pada genteng menggunakan alat compression test. Sedangkan pengukuran daya serap air dilakukan dengan mengukur persentase selisih berat genteng sebelum dan setelah direndam ke dalam air selama satu malam. Hasil penelitian menunjukkan bahwa dengan meningkatkan suhu pembakaran akan meningkatkan nilai kuat tekan dan menurunkan nilai daya serap genteng terhadap air. Penambahan serbuk kaca yang memberikan nilai kuat tekan tertinggi dan daya serap air terendah adalah pada penambahan serbuk kaca $12 \%$. 


\section{Pendahuluan}

Genteng merupakan salah satu komponen penting pembangunan perumahan yang memiliki fungsi untuk melindungi rumah dari suhu, hujan maupun fungsi lainnya. Semakin banyak pembangunan perumahan, maka akan semakin banyak kebutuhan akan genteng. Atap genteng dari tanah liat saat ini paling banyak digunakan oleh masyarakat Indonesia karena harganya yang relatif terjangkau dan mudah didapatkan. Pembuatan genteng menggunakan metode sederhana dimulai dari pengambilan tanah lempung sebagai bahan dasar, penggilingan lempung, pencetakan genteng dan pembakaran genteng [1] serta menggunakan bahan tambahan hanya berupa pasir kali memiliki banyak kelemahan. Kelemahan tersebut antara lain genteng mudah retak, memiliki daya serap air yang tinggi dan memiliki kuat tekan yang rendah. Menurut penelitian Sinha Ray, dkk. [2] pemberian bahan tambahan pada proses pembuatan genteng sangat berpengaruh terhadap kuat tekan dan porositas genteng. Oleh karena itu, perlu dikembangkan metode pembuatan genteng yang lebih baik dengan memberikan bahan tambahan seperti batu padas, sekam padi dan bubuk silika.

Penambahan silika sebagai bahan alternatif sering digunakan dalam proses pembuatan genteng dikarenakan memiliki kelebihan yaitu sebagai subyek untuk mengubah bentuk dan volume lempung pada suhu tertentu [3]. Pada gerabah padat, silika berfungsi sebagai bahan pengisi yang memelihara bentuk gerabah selama pembakaran [4]. Silika dan alumina akan membentuk sebuah jaringan kristal yang mengikat bahan-bahan yang tidak dapat dilarutkan menjadi suatu massa yang kuat. Silika yang menjadi bahan tambahan untuk pembuatan genteng dapat diperoleh dari botol kaca, sebab botol kaca dibuat dari kaca soda gamping yang memiliki kandungan silika tinggi yaitu 72,4\% [5].

Suhu pembakaran juga sangat mempengaruhi proses pembuatan genteng. Semakin tinggi suhunya maka silika akan mengelas memasuki pori-pori dan mengikat semua partikel lempung dengan membentuk ikatan yng dikenal sebagai ikatan alumina silika [6].

Bahan dasar pembuatan genteng adalah lempung. Di aliran sungai Banjir Kanal Timur Kota Semarang terdapat deposit tanah lempung yang sangat banyak, membentang dari selatan hingga utara sepanjang $12 \mathrm{~km}$. Besarnya sedimentasi lempung tersebut mempengaruhi aliran air sungai Banjir Kanal Timur yang dapat mengakibatkan musibah banji. Sampai sekarang sedimen lempung dari Banjir Kanal kota Semarang belum dimanfaatkan. Sehingga pada penelitian ini dicoba mengkaji pemanfaatan tanah lempung Banjir Kanal Timur kota Semarang untuk pembuatan genteng.

Penelitian ini dilakukan dengan memodifikasi prosentase serbuk kaca botol bekas sebagai sumber silica dengan variasi suhu pembakaran $600^{\circ} \mathrm{C}, 700^{\circ} \mathrm{C}$, $800^{\circ} \mathrm{C}, 900^{\circ} \mathrm{C}$ pada pembuatan genteng dari lempung Banjir Kanal Timur kota Semarang. Hal ini bertujuan untuk mengetahui suhu pembakaran yang efisien sehingga dihasilkan genteng yang memiliki kuat tekan tinggi dan daya serap air rendah.

\section{Metodologi}

\subsection{Alat}

Alat yang digunakan dalam penelitian ini antara lain adalah ayakan ukuran 100 mesh, timbangan analitis, oven, furnace, blender, alat pencetak genteng, dan compression test untuk uji daya tekan genteng silik

\subsection{Bahan}

Lempung alam yang berasal dari kali Banjir Kanal Timur jalan Barito Kota Semarang, bubuk kaca dari botol bekas, dan air.

\subsection{Cara Kerja}

\section{Preparasi Lempung}

Lempung Banjir Kanal Timur dari daerah Barito dibersihkan dari pengotor-pengotornya. Jika lempung yang digunakan terdapat bagian yang mengeras dan dapat mengganggu proses homogenasi, perlu dilakukan pengayakan pada lempung

\section{Preparasi Sampel Kaca Sebagai Bubuk Kaca}

Kaca dibersihkan dari pengotor-pengotornya kemudian dikeringkan. Kaca bersih dan kering dihaluskan sampai terbentuk serbuk kaca halus, kemudian diayak dengan ayakan 100 mesh.

\section{Pembuatan Genteng Silika}

Pembuatan genteng silika dilakukan dengan mencampurkan lempung yang sudah melalui tahap preparasi kemudian ditambahkan dengan bubuk kaca sebagai sumber silika dan air secukupnya sebagai perekat. Variasi komposisi bubuk kaca adalah $0 \%, 2 \%$, $4 \%, 6 \%, 8 \%, 10 \%, 12 \%, 14 \%, 16 \%, 18 \%, 20 \%$ dari berat total, yaitu 200 gram. Komposisi antar lempung dan serbuk kaca seperti tercantum dalam tabel 1 sebagai berikut

Tabel 1. Komposisi lempung, serbuk kaca dan air

\begin{tabular}{ccc}
\hline $\begin{array}{c}\text { Berat lempung } \\
(\text { gram })\end{array}$ & $\begin{array}{c}\text { Berat serbuk } \\
\text { kaca (gram) }\end{array}$ & Air (mL) \\
\hline 200 & 0 & \pm 20 \\
196 & 4 & \pm 20 \\
192 & 8 & \pm 20 \\
188 & 12 & \pm 20 \\
184 & 16 & \pm 20 \\
180 & 20 & \pm 20 \\
176 & 24 & \pm 20 \\
172 & 28 & \pm 20 \\
168 & 32 & \pm 20 \\
164 & 36 & \pm 20 \\
160 & 40 & \pm 20 \\
\hline
\end{tabular}

Lempung, serbuk kaca dan air dihomogenasi dengan menggunakan blender, kemudian disaring dan 
diangin-anginkan sampai setengah kering untuk memudahkan proses pencetakan atau pengepresan. Kemudian ditimbang \pm 50 gram dan di-press atau dicetak dengan alat pengepres.

Pencetakan dilakukan dengan cara diberi tekanan sehingga menjadi padat. Genteng yang sudah dicetak dikeringkan dengan oven dengan suhu $80^{\circ} \mathrm{C}$ selama $\pm 1,5$ jam. Genteng kering kemudian dibakar dengan furnace dengan variasi suhu $600^{\circ} \mathrm{C}, 700^{\circ} \mathrm{C}, 800^{\circ} \mathrm{C}, 900^{\circ} \mathrm{C}$.

\section{Pengujian Genteng}

\section{Uji daya serap terhadap air}

Genteng yang sudah dibakar ditimbang terlebih dahulu sebagai berat awal. Kemudian genteng direndam dalam air selama 1 hari (semalaman), genteng diambil dan dibiarkan selam 1 jam. Kemudian ditimbang kembali sebagai berat akhir. Penghitungan daya serap genteng dilakukan dengan menghitung selisih berat awal dan berat akhir kemudian membaginya dengan berat awal.

\section{Uji kuat tekan}

Uji daya tekan dilakukan untuk mengetahui kekuatan dari genteng, sampel yang sudah diuji daya serapnya dikeringkan, kemudian di ampelas sampai sama rata permukaannya. Genteng yang akan diuji diletakkan pada mesin penekan. Genteng ditekan dengan alat penekan sampai genteng pecah. Pada saat pecah dicatat besarnya gaya tekan maksimum yang bekerja.

\section{Uji FTIR}

Genteng yang digunakan, dikarakterisasi gugus fungsi yang terdapat dalam strukturnya dengan spektroskopi FTIR.

\section{Hasil dan Pembahasan}

Telah dilakukan pemanfaatan lempung sedimentasi Banjir Kanal Timur kota Semarang untuk pembuatan genteng dan pengaruh penambahan serbuk kaca sebagai sumber silika serta variasi suhu pembakaran terhadap kuat tekan dan daya serap air. Tahapan yang dilakukan meliputi preparasi lempung, preparasi kaca, pembuatan genteng dan untuk mengetahui kualitas genteng dilakukan uji perembesan air dan uji kuat tekan genteng.

\subsection{Pembuatan Genteng}

Pada penelitian ini genteng dibuat dengan menggunakan lempung banjir kanal timur kota Semarang dengan ditambahkan botol kaca bekas transparan (tidak berwarna) jenis soda gamping (sodalime glass) dan dihaluskan. Kaca yang digunakan tidak berwarna karena dengan tidak adanya warna akan sedikit mengandung oksida-oksida logam atau garam sehingga reaksi dapat berjalan sempurna [7]. Tujuan penghalusan adalah untuk penyamarataan permukaan kaca dan memudahkan proses homogenasi dengan lempung.

Modifikasi pembuatan genteng dengan penambahan serbuk kaca dilakukan pada berbagai variasi berat serbuk kaca $0-20 \%$ terhadap berat total genteng basah. Penambahan serbuk kaca dapat mengurangi susut bakar melalui pengisian pori-pori oleh silika pada lempung pada saat pembakaran berlangsung. Proses pencetakan dilakukan dengan tujuan memberi tekanan pada lempung agar padat sehingga memiliki bentuk.

Proses pengeringan dilakukan untuk menghilangkan air plastis yang terikat pada genteng. Pada proses pengeringan beberapa sampel genteng mengalami keretakan. Keretakan ini disebabkan oleh proses pengeringan yang terlalu cepat air hilang secara tiba-tiba tanpa diimbangi penataan partikel tanah liat secara sempurna. Untuk menghindari pengeringan yang terlalu cepat, pada tahap awal genteng dianginanginkan pada suhu kamar. Kemudian dikeringkan dengan sinar matahari langsung atau oven.

Genteng dibakar dengan variasi suhu $600^{\circ} \mathrm{C}, 700^{\circ} \mathrm{C}$, $800^{\circ} \mathrm{C}, 900^{\circ} \mathrm{C}$ menggunakan furnace dengan tujuan untuk melelehkan kaca sehingga silika yang dikandung kaca dapat mengisi pori-pori genteng. Perubahan pertama yang terjadi dalam lempung ketika dibakar adalah hilangnya air bebas yaitu air yang ditambahkan dan berada di permukaan pada temperatur $\pm 150^{\circ} \mathrm{C}$ [8]. Agar lempung menjadi genteng harus melalui proses pembakaran dengan suhu melebihi $600^{\circ} \mathrm{C}$, pada temperatur antara $400^{\circ} \mathrm{C}-600^{\circ} \mathrm{C}$ air yang terikat secara kimia dan zat-zat lain di dalam lempung akan menguap. Setelah suhu lebih dari $600^{\circ} \mathrm{C}$ lempung akan mengalami perubahan menjadi suatu mineral yang padat, keras dan permanen, perubahan ini disebut ceramic change atau perubahan keramik [6].

\section{Uji Spektroskopi Infra Merah}

Uji FTIR pada penelitian ini dilakukan terhadap lempung Banjir Kanal Timur kota Semarang yang dibandingkan dengan genteng. Hasil analisis FTIR pada sampel lempung dan genteng dapat disajikan pada gambar 1.

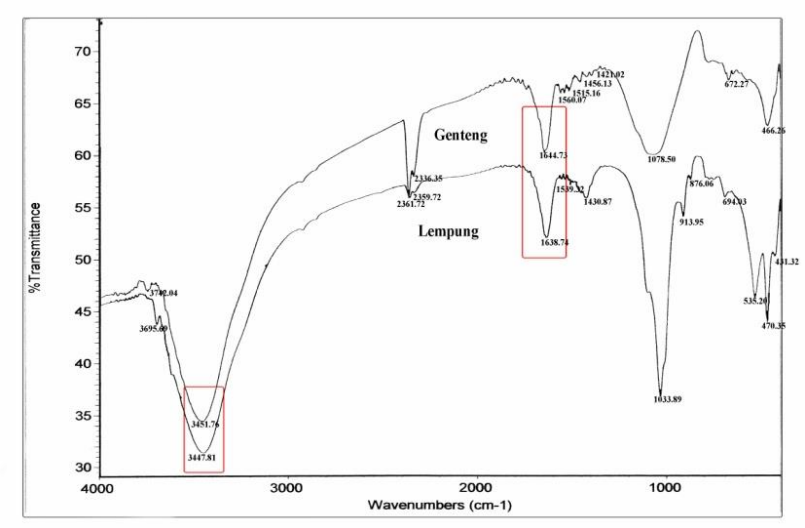

Gambar 1. spektra FTIR dari lempung dan sampel genteng

Gambar 1 di atas menunjukkan adanya perbedaan spektra lempung dan spektra genteng. Spektra pada puncak 3447,81 $\mathrm{cm}^{-1}$ merupakan uluran $-\mathrm{OH}$ yang terikat pada -Al, spektra pada lempung memiliki transmitansi lebih rendah daripada transmitansi pada genteng, hal itu membuktikan bahwa dengan adanya 
pemanasan maka - OH yang terikat pada -Al banyak terlepas dan diduga hal itu mengakibatkan terbentuk ikatan dengan SiO, membentuk ikatan silika alumina, ikatan yang terjadi adalah ikatan kovalen.

Serapan $1638,74 \mathrm{~cm}^{-1}$ terdeteksi sebagai vibrasi tekuk dari air terhidrat, spektra ini terdapat pada sampel lempung dan genteng, hal ini menjelaskan bahwa masih ada air yang terdapat pada lempung dan genteng. Air terhidrat dalam genteng adalah air yang terjebak dalam pori di permukaan genteng.

Puncak 1033,89 $\mathrm{cm}^{-1}$ mengidentifikasi adanya serapan gugus siloksan pada sampel lempung yaitu regangan asimetris ikatan $\mathrm{O}-\mathrm{Si}-\mathrm{O}$ dalam $\mathrm{TO}_{4}$, hal ini menunjukkan bahwa lempung mengandung silika. Pada sampel genteng serapan terdapat pada puncak 1078,5 $\mathrm{cm}^{-1}$ yang menyatakan adanya fasa metakaolin, tetapi transmitasinya cukup besar yang menyatakan bahwa jumlah konsentrasi metakaolin dalam genteng sedikit. Metakaolin terjadi karena pemanasan yang mengakibatkan lepasnya $\mathrm{H}_{2} \mathrm{O}$. Persamaan reaksinya pembentukan metakaolin menurut Kasmayadi dan Murwani [9] adalah sebagai berikut:

$$
\mathrm{Al}_{2} \mathrm{O}_{3} .2 \mathrm{SiO}_{2} .2 \mathrm{H}_{2} \mathrm{O} \rightarrow-\mathrm{Al}_{2} \mathrm{O}_{3} .2 \mathrm{SiO}_{2}+2 \mathrm{H}_{2} \mathrm{O} \uparrow
$$

$$
\text { metakaolin }
$$

Karakterisasi FTIR pada daerah sedang menunjukkan adanya serapan pada daerah sekitar 450 $\mathrm{cm}^{-1}$ dengan intensitas yang tidak jauh berbeda untuk masing-masing sampel. Serapan pada daerah ini mengindikasikan adanya vibrasi tekuk $\mathrm{Si}-\mathrm{O}$ atau $\mathrm{Al}-\mathrm{O}$, sehingga dapat dijelaskan bahwa pada sampel genteng maupun sampel lempung terdapat $\mathrm{Si}-\mathrm{O}$ dan $\mathrm{Al}-\mathrm{O}$.

Serapan 2361,72 $\mathrm{cm}^{-1}$ yang muncul pada fasa genteng adalah fasa pembentukan mullite $\left(2 \mathrm{Al}_{2} \mathrm{O}_{3} \cdot 2 \mathrm{SiO}_{2}\right)$, hal ini sesuai dengan penelitian [10], serapan ini tidak muncul pada sampel lempung sebab fasa mullite terbentuk apabila suhu pembakaran genteng tinggi atau lebih dari $900^{\circ} \mathrm{C}$. Penelitian Kasmayadi dan Murwani [9] menyatakan pembentukan mullite terjadi pada suhu $934,39^{\circ} \mathrm{C}$. Mullite merupakan senyawa yang sangat stabil, sehingga dapat dikatakan pembentukan mullite ini merupakan tujuan dari pembakaran keramik, karena dengan adanya mullite, sifat-sifat keramik yang keras, kompak, dan padat mulai terbentuk. Pendapat lain mengenai pembentukan fasa mullite terdapat dalam penelitian [11] yang menyatakan fasa mullite terbentuk di atas suhu $1000^{\circ} \mathrm{C}$. Hal ini mempertegas pernyataan bahwa genteng yang dibakar pada suhu pembakaran $900^{\circ} \mathrm{C}$ akan memiliki kuat tekan yang tinggi dan daya serap yang rendah karena fasa mullite telah terbentuk. Reaksi terjadinya reaksi mullite menurut Susetyaningsih [12] adalah sebagai berikut:

$$
\begin{aligned}
& 2\left(\mathrm{Al}_{2} \mathrm{O}_{3} \cdot 2 \mathrm{SiO}_{2}\right) \longrightarrow \\
& \mathrm{Al}_{2} \mathrm{O}_{3} \cdot 2 \mathrm{SiO}_{2} \longrightarrow 2 \mathrm{Al}_{2} \mathrm{O}_{3} \cdot 3 \mathrm{SiO}_{2}+\mathrm{SiO}_{2} \\
& \rightarrow 2 \mathrm{Al}_{2} \mathrm{O}_{3} \cdot 2 \mathrm{SiO}_{2}+\mathrm{SiO}_{2}
\end{aligned}
$$

\section{Uji Kuat Tekan}

Uji kuat tekan menggunakan alat commpression test untuk mengetahui pengaruh penambahan serbuk kaca dan suhu pembakaran genteng terhadap kuat tekan dari genteng Hasil uji kuat tekan genteng lempung Banjir Kanal Timur Kota Semarang disajikan pada Gambar 2

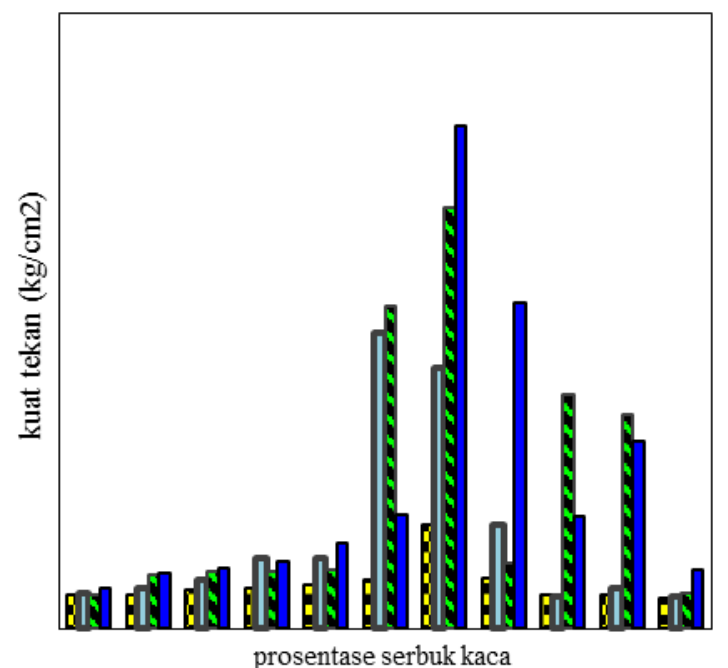

घ600C $\mathbf{0} 700 \mathrm{C} \mathbf{8} 800 \mathrm{C} \quad \mathbf{9} 900 \mathrm{C}$

Gambar 2 Grafik pengaruh prosentase serbuk kaca dan suhu pada kuat tekan genteng

Gambar 2 menunjukkan bahwa penambahan serbuk kaca meningkatkan kuat tekan. Peningkatan kuat tekan ini disebabkan partikel-partikel silika mulai mengisi ruang antar partikel tanah liat, akibatnya muncul ikatan antara partikel lempung dan silika. Semakin besar prosentase serbuk kaca semakin banyak ikatan yang terbentuk sehingga kekuatan semakin meningkat dan pori-pori semakin rapat. Mekanisme pengisian ruang antar partikel lempung oleh silika disajikan pada Gambar 3.

Penambahan serbuk kaca yang tertinggi diperoleh pada prosentase $12 \%$ dari rentang 0\%-20\%. Hal tersebut karena volume silika $12 \%$ yang ditambahkan sama dengan volume ruang kosong antar partikel lempung. Penambahan serbuk kaca pada genteng kurang dari $12 \%$ atau tanpa penambahan menghasilkan kuat tekan genteng yang tidak begitu tinggi, karena jumlah silika yang ditambahkan belum mencukupi untuk menutup semua pori. Jika serbuk kaca yang ditambahkan lebih dari $12 \%$ nilai kuat tekan menurun, sebab kadar $\mathrm{SiO} 2$ pada pori-pori lempung sudah jenuh, sehingga kristalinitasnya berkurang sesuai dengan penelitian Hadiyawarman, $d k k$. [13].

Suhu juga berpengaruh pada kuat tekan genteng. Dalam pembakaran, partikel-partikel yang semula terikat lemah karena hanya melakukan kontak lemah satu sama lain, mulai memperluas permukaan kontak akibat difusi atom. Kontak tersebut tumbuh menjadi leher (neck), yang ukurannya bergantung pada lama pemanasan dan suhu pemanasan [14]. Semakin lama waktu pemanasan dan tingginya suhu pemanasan maka ukuran leher semakin besar sehingga ikatan antar partikel semakin kuat. Ketika material yang disusun oleh partikel-partikel tersebut dibakar maka luas permukaan kontak partikel tumbuh, namun ruang kosong antar partikel tetap ada, tidak mungkin menghilangkan ruang kosong kecuali terjadi 
penyusutan volume total material. Mekanisme penyatuan partikel menurut [15] ditampilkan pada gambar 3.

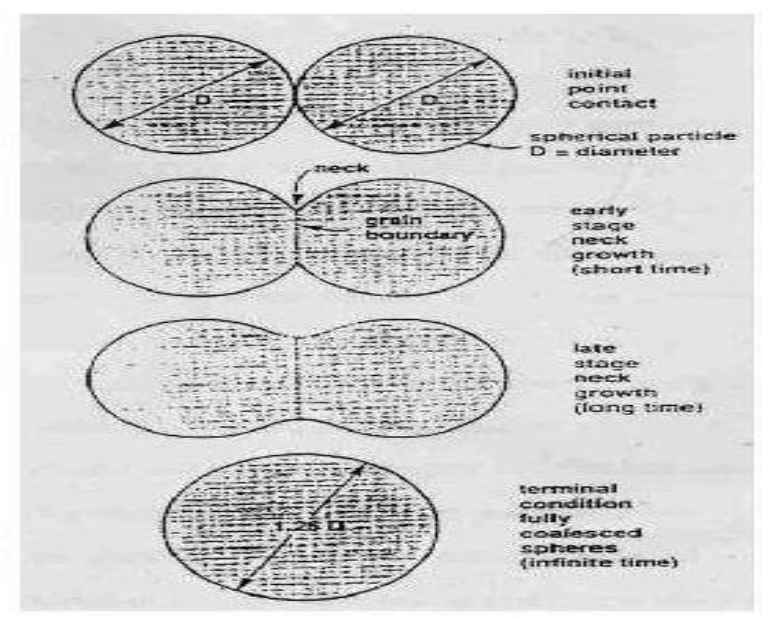

Gambar 3 Mekanisme penyatuan leher antarpartikel

Hasil uji kuat tekan genteng yang dibakar pada suhu $900^{\circ} \mathrm{C}$ memiliki kuat tekan paling tinggi karena sudah mulai mengalami fasa pembentukan kristalin yaitu fasa mullite, selain itu pada suhu $900^{\circ} \mathrm{C}$ genteng sudah mengalami proses vitrifikasi. Menurut [16] lempung akan menguat saat mengalami vitrifikasi yang dimulai pada suhu $900^{\circ} \mathrm{C}$ dan akan bertambah terus kekuatannya saat temperatur semakin dinaikkan sampai suhu maksimal lempung $1500^{\circ} \mathrm{C}$. Selama vitrifikasi pori akan mengecil dan kekuatan serta kepadatan naik.

Genteng yang dibakar pada suhu $600^{\circ} \mathrm{C}$ memiliki nilai kuat tekan terendah sebab genteng baru mengalami reaksi dehidroksilasi berupa hilangnya molekul air yang terserap pada kisi-kisi kristal dan menuju pada pembentukan metakaolin. Metakaolin merupakan senyawa antara menuju senyawa berikutnya (mullite). Pembakaran pada suhu lebih dari $800^{\circ} \mathrm{C}$ menyebabkan genteng mulai mengalami pembentukan fasa kristalin dari metakaolin, sehingga pada suhu pembakaran $700^{\circ} \mathrm{C}-800^{\circ} \mathrm{C}$ hasil kuat tekan genteng belum maksimal.

Hasil penelitian ini juga menunjukkan fenomena yang sama bahwa semakin tinggi suhu, maka semakin besar kuat tekannya sesuai dengan penelitian [17-19]. Nilai kuat tekan pada suhu lebih tinggi semakin meningkat disebabkan turunnya volume pori lempung. Hal ini didukung pula oleh penelitian [20] yang menyatakan kenaikan suhu bakar ternyata memungkinkan munculnya mineral mullite yang membuat kekuatan keramik jauh lebih baik.

Data yang dihasilkan terdapat nilai yang kurang baik yaitu pada suhu $700^{\circ} \mathrm{C}$. Nilai kuat tekan yang dihasilkan kurang maksimum, kemungkinan disebabkan oleh sisi genteng yang kurang rata. Permukaan yang kurang rata menyebabkan hanya sebagian permukaan genteng yang bersinggungan dengan plat pada mesin uji kuat tekan. Menurut van Vlack dan Djaprie [4] kuat tekan maksimum hanya akan dihasilkan bila seluruh permukaan genteng bersinggungan seluruhnya dengan plat baja pada mesin uji tekan

\section{Uji Daya Serap Air}

Genteng yang telah dibakar kemudian diuji daya serapnya untuk mengetahui pengaruh penambahan serbuk kaca dan pengaruh suhu pembakaran pada kemampuan daya serap genteng terhadap air. Grafik prosentase serapan air pada genteng yang telah direndam ditunjukkan oleh Gambar 4.

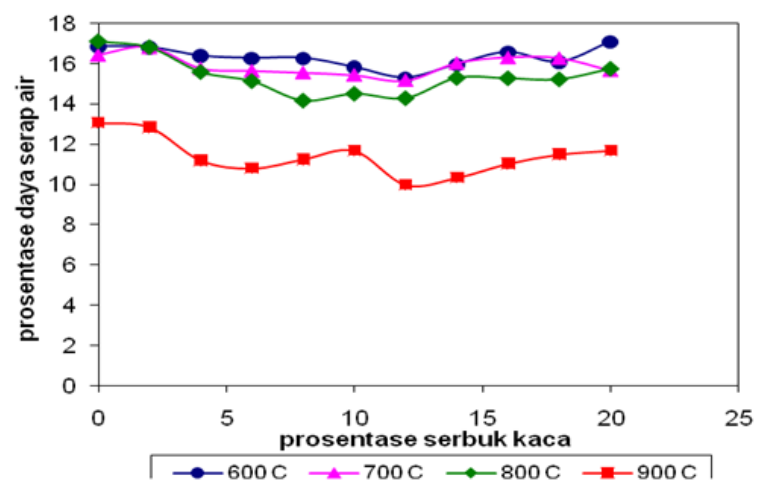

Gambar 4. Prosentase serapan air genteng

Gambar 4 menunjukkan semakin tinggi suhu, maka nilai prosentase air semakin rendah. Lempung yang dibakar kurang dari $600^{\circ} \mathrm{C}$ belum memiliki kematangan yang tepat. Penelitian Almarahle [21] menyatakan bahwa air pada lempung mulai menguap pada suhu $105^{\circ} \mathrm{C}$ sampai antara $700^{\circ} \mathrm{C}-800^{\circ} \mathrm{C}$.

Conrad [6] menyatakan bahwa lebih dari suhu $800^{\circ} \mathrm{C}$, terjadi perubahan-perubahan kristal dari lempung dan mulai terbentuk bahan gelas yang mengisi pori-pori, sehingga bahan menjadi padat dan kuat. Semakin tinggi suhu maka silika akan mengelas memasuki pori-pori dan mengikat semua partikel tanah liat dengan membentuk ikatan yang dikenal sebagai ikatan alumina silika. Adanya pengelasan maka pori-pori genteng semakin rapat, sehingga air tidak banyak yang menembus. Pori sangat mempengaruhi daya serap air semakin banyak pori maka akan meningkatkan daya serap air. Saat lempung dibakar pada suhu lebih dari $800^{\circ} \mathrm{C}$ beberapa perubahan akan terjadi, misalnya lempung menjadi lebih keras ketika mendingin dan menjadi kedap air. Lempung tersebut telah mengalami proses vitrifikasi. Proses vitrifikasi ini disertai dengan penyusutan volume, semakin tinggi suhu, semakin besar penyusutan tetapi semakin rendah porositasnya, atau dengan kata lain benda semakin padat dan kedap air [6]. Menurut Kizinievic, dkk. [22] semakin tinggi suhu, maka daya serap akan menurun karena menurunnya volume pori.

Pembakaran suhu $600^{\circ} \mathrm{C}$ memiliki nilai daya serap paling besar karena genteng belum memiliki kematangan yang tepat. Pada suhu $700^{\circ} \mathrm{C}$ dan $800^{\circ} \mathrm{C}$ nilai daya serap genteng mengalami penurunan karena pori-pori lempung semakin mengecil dan saat genteng dibakar pada suhu $900^{\circ} \mathrm{C}$ daya serapnya semakin rendah karena genteng sudah mengalami proses vitrifikasi yang mengakibatkan semakin menyusutnya pori-pori 
genteng. Semakin tinggi suhunya semakin rendah nilai prosentase daya serap pada genteng.

Penambahan serbuk kaca juga sangat berpengaruh pada daya serap genteng. Hal ini disebabkan tanpa serbuk kaca ruang antar partikel lempung berupa ruang kosong karena lepasnya air akibat pemanasan. Penyusunan partikel-partikel akan menimbulkan celah yang ukurannya lebih kecil daipada ukuran partikel lempung. Sehingga memungkinkan pengisian celah antar partikel tersebut dengan partikel yang ukurannya lebih kecil dari ukuran celah dan kontak yang dialami partikel lempung makin banyak. Kontak tidak hanya terjadi antar partikel lempung tetapi juga antara partikel lempung dengan partikel-partikel kecil yang mengisi ruang kosong sesuai dengan penelitian [14]. Penambahkan serbuk kaca akan mengisi pori-pori, silika dalam serbuk kaca berperan sebagai pengelas saat dipanaskan dengan suhu tinggi. Menurut Cole [23] silika akan menaikkan suhu vitrifikasi, tetapi mengurangi penyusutan pada saat proses pengeringan dan pembakaran

Silika yang dibakar pada suhu cukup tinggi berubah menjadi cairan gelas yang mengisi pori-pori sehingga bahan menjadi padat dan kuat. Tanpa adanya partikel silika, genteng mejadi berongga dan dengan adanya partikel silika, rongga genteng semakin menyempit. Penyempitan rongga genteng ini yang menyebabkan air tidak mudah masuk ke dalam genteng.

Penambahan serbuk kaca $12 \%$ memiliki nilai daya serap yang paling rendah, hal ini karena silika yang ditambahkan telah menutup pori lempung. Penambahan serbuk kaca kurang dari $12 \%$ menjadikan genteng memiliki daya serap yang tinggi sebab masih banyaknya pori genteng yang belum tertutup. Pada penambahan serbuk kaca lebih dari $12 \%$ nilai prosentase daya serapnya juga mulai bertambah. Hal ini disebabkan dengan semakin banyaknya serbuk kaca dalam pori menjadikan suhu vitrifikasi naik, sehingga proses penyempitan pori menjadi terhambat.

Berdasarkan uji kuat tekan dan daya serap air terhadap genteng disimpulkan bahwa kuat tekan semakin meningkat apabila daya serap air semakin rendah Lempung sedimentasi Banjir Kanal Timur kota Semarang bisa dijadikan alternatif pembuat genteng dengan menambahkan serbuk kaca $12 \%$, sehingga dapat mengurangi sedimentasi pada sungai Banjir Kanal Timur kota Semarang.

\section{Kesimpulan}

Berdasarkan hasil uji dalam penelitian ini, lempung Banjir Kanal Timur kota Semarang dapat digunakan sebagai bahan baku pembuatan genteng. Penambahan serbuk kaca meningkatkan kuat tekan dan menurunkan daya serap air dengan penambahan optimal pada $12 \%$. Nilai kuat tekan genteng meningkat dan daya serap menjadi rendah pada temperatur $900^{\circ} \mathrm{C}$.

\section{Daftar Pustaka}

[1] Masciput, Templek Daerah Pengrajin Genteng, in, 2008.

[2] Suprakas Sinha Ray, Kazuaki Okamoto, Kazunobu Yamada, Masami Okamoto, Novel porous ceramic material via burning of polylactide/layered silicate nanocomposite, Nano Letters, 2 (2002) 423-425.

[3] Ambar Astuti, Pengetahuan Keramik, Gajah Mada University Press, Yogyakarta, 1997.

[4] Lawrench H van Vlack, Sriati Djaprie, Ilmu dan teknologi Bahan, Penerbit Erlangga, 1992.

[5] S Scholes, Modern Glass Practice, revised by Charles H. Greene, in, RAN Publishers, 1975.

[6] John W Conrad, Contemporary ceramic formulas, Macmillan Pub Co, 1980.

[7] A Rohman, Pembuatan Silika Gel untuk Kromatografi Lapis Tipis dari Botol Bekas, Lembaga Penelitian universitas Airlangga, Surabaya, 54 (1996).

[8] S Gesang, JMV Hartono, Teknologi Bahan Bangunan Bata dan Genteng, in, Balai Penelitian Keramik, Bandung, 1979.

[9] Wirman Kasmayadi, Irmina Kris Murwani, Analisis Termal Dan Studi Transformasi Fase Sistem Badan Keramik Lempung Batu Kumbung Lombok, Feldspar, Akta Kimindo, 3 (2007) 43-48.

[10] DR Treadwell, DM Dabbs, IA Aksay, Mullite (3Al2O3-2SiO2) synthesis with aluminosiloxanes, Chemistry of materials, 8 (1996) 2056-2060.

[11] Akira Nishikawa, Technology of monolithic refractories, Plibrico Japan company limited, (1984).

[12] Retno Susetyaningsih, Endro K Ismolo ,Kristri Basuki Pengaruh Penambahan MgO Pada Peningkatan Kualitas Lempung Kasongan Untuk Immobilisasi Lumpur Limbah $\mathrm{Pb}$ Menggunakan Teknologi Keramik, Jurnal Sekolah Tinggi Teknologi Nuklir (2008).

[13] Hadiyawarman, Agus Rijal, Bebeh Wahid Nuryadin, Mikrajuddin Abdullah, Khairurrijal, A., Nuryadin BW, Abdullah M. dan Khairurrijal.(2008). Fabrikasi Material Nanokomposit Superkuat, Ringan dan Transparan Menggunakan Metode Simple Mixing, Jurnal Nanosains \& Nanoteknologi, 1 (2008) 14-21.

[14] Mikrajuddin Abdullah, A.D. Sonya, Bebeh Wahid Nuryadin, AR Marully, Khairurrijal, Sintesis Keramik Berbasis Komposit Clay-Karbon dan Karakterisasi Kekuatan Mekaniknya, Jurnal Nanosains \& Nanoteknologi, 2 (2009).

[15] Randall M German, Powder metallurgy and particulate materials processing: the processes, materials, products, properties, and applications, Metal powder industries federation Princeton, NJ, 2005.

[16] NA Mazen, Production of fire clay refractory bricks from local materials, European Journal of Scientific Research, 26 (2009) 386-392.

[17] Sedat Karaman, Sabit Ersahin, Hikmet Gunal, Firing temperature and firing time influence on mechanical and physical properties of clay bricks, 
Journal of scientific and Industrial research, 65 (2006) 153.

[18] Tütünlü Fatih, Atalay Umit, Utilization of fly ash in manufacturing of building brick, in: International ash utilization symposium. Center for applied energy research, University of Kentucky Paper, 2001.

[19] K Haruna, P Onoja, M Chiroma, Characterization of Mayo-Belwa clays, Leonardo Electronic J. Practices Technol, 6 (2007) 123-130.

[20]Humbarsono, Lempung Serap Tanjungharjo Sebagai Pencampur Lempung G. Pare Godean Untuk Bahan Keramik Melalui Kajian Mineralogi Di Pundong Bantul Yogyakarta, Jurnal Riset Daerah Vol.VI, No.1: 700-743. (2007).

[21] Gazze Almarahle, Production of silica-refractory bricks from white sand, American Journal of Applied Sciences, 2 (2005) 465-468.

[22]Olga Kizinievic, Ramunè Zurauskiene, Algis Spokauskas, Romualdas Maciulaitis, Application of catalyst waste to ceramics made of raw materials, Materials Science (Medžiagotyra), 11 (2005).

[23]WF Cole, A note on the practical values of clay mineralogy in coarse ceramics, Clay Min. Bull, 4 (1960) 134-141. 